\title{
Balkanologie
}

Balkanologie Revue d'études pluridisciplinaires

Vol. III, n² | 1999

Volume III Numéro 2

\section{de Montclos (Christine), Le Vatican et l'éclatement de la Yougoslavie}

Paris : PUF, 1999, 263 p. [Bibliogr. Chrono. Annexes]

\section{Patrick Michels}

\section{(2) OpenEdition}

\section{Journals}

Édition électronique

URL : http://journals.openedition.org/balkanologie/2193

DOI : 10.4000/balkanologie.2193

ISSN : 1965-0582

Éditeur

Association française d'études sur les Balkans (Afebalk)

Édition imprimée

Date de publication : 1 décembre 1999

ISSN : 1279-7952

\section{Référence électronique}

Patrick Michels, « de Montclos (Christine), Le Vatican et l'éclatement de la Yougoslavie », Balkanologie [En ligne], Vol. III, n² | 1999, mis en ligne le 22 juin 2010, consulté le 17 décembre 2020. URL : http:// journals.openedition.org/balkanologie/2193; DOI : https://doi.org/10.4000/balkanologie.2193

Ce document a été généré automatiquement le 17 décembre 2020.

(c) Tous droits réservés 


\title{
de Montclos (Christine), Le Vatican et l'éclatement de la Yougoslavie
}

\author{
Paris : PUF, 1999, 263 p. [Bibliogr. Chrono. Annexes]
}

\section{Patrick Michels}

\section{RÉFÉRENCE}

de Montclos (Christine), Le Vatican et l'éclatement de la Yougoslavie, Paris : PUF, 1999, 263 p. [Bibliogr. Chrono. Annexes]

C. de Montclos a écrit un livre intéressant sur la politique du Vatican par rapport à l'éclatement de la Yougoslavie. Évitant la plupart des clichés véhiculés par la presse et nombre de "spécialistes spontanés", elle offre aux lecteurs un travail de recherche mêlant analyses historiques et de politique internationale. Le Vatican ne pouvait pas rester indifférent à ce qui se déroulait en Yougoslavie, du fait qu'une partie des acteurs étaient catholiques, que les évêques croates ont mobilisé les épiscopats des différents États. De plus, le Vatican était bien plus sensible aux revendications exprimées par les catholiques que par les autres religions (d'où son appel à voter pour la HDZ, Hrvatska Demokratska Zajednica, Communauté Démocratique Croate, en 1990). Toutefois, c'est la presse vaticane (Osservatore Romane) qui a été la plus virulente dans son soutien à la cause des républiques slovène et croate, notamment par anticommunisme. Mais le Vatican n'a pas non plus été très critique envers l'état croate à ses débuts, étant donné que «l'action dans l'urgence exclut la prise en compte des causes plus profondes et moins actuelles» (p. 92), il n'a pas non plus «cherché à mobiliser les instances internationales avec la même intensité que dans l'ancienne Yougoslavie » dans le cas des autres guerres se déroulant de par le monde. Le Vatican a tenté de ne pas affirmer de position radicale, en prenant conscience du nationalisme du régime croate et, également, pour éviter de s'aliéner le monde orthodoxe slave, et, enfin, parce qu'étant 
une autorité morale, il ne peut que donner conseils et avis (ce que le Vatican se contentera de faire pour la Bosnie-Herzégovine).

2 C. de Montclos opère une lecture balancée, ni pro-vaticane, ni anti-serbe. Elle a réalisé un travail sérieux d'analyse qui n'est, malheureusement pas, exempt de défauts, tenant au mauvais système d'information dont la Yougoslavie (entre autres) a bénéficié dans la presse. Il y a d'abord des erreurs typographiques (espérons-le) : le coup d'État du 27 mars 1942 arrive un peu tard (p. 10), Josip Broz Tito devient Josef (p. 10). Ensuite, des erreurs d'interprétation : le mémorandum de l'Académie serbe des Sciences et des Arts (ASSA) est « largement diffusé à partir de 1986 » (p. 11), alors que l'étude critique du titisme (effectuée dans un état d'esprit certes spécial) n'a jamais été terminée et que c'est l'ébauche d'un mémorandum qui a circulé ; Franjo Tuđman n'a pas été élu en 1990 (p. 15), mais désigné par le Parlement; le séparatisme croate en Bosnie-Herzégovine n'est pas "renaissant" en 1996 (p. 155). Enfin, une méconnaissance de la constitution yougoslave : la distinction narod / narodnost n'est pas connue de l'auteur (p. 18), qui est persuadée que le droit de sécession est reconnu dans la constitution yougoslave ( $p$. 69). On regrettera également les nombreuses références au slaviste $P$. Garde, alors que des spécialistes français (historiens, sociologues, politologues, ...) de l'“ex-Yougoslavie" existent. Le plus surprenant provient de la chronologie, qui rassemble les "grandes étapes de l'éclatement de la Yougoslavie» (p. 197, n. 1). Elle débute par «1980, 4 mai, mort de Tito » : la Yougoslavie ne pouvait donc pas exister sans Tito ? L'entrée suivante est 1986, avec les premières manifestations nationalistes serbes au Kosovo et le mémorandum de l'ASSA. Il ne s'est donc rien passé en 1981, et on n'apprendra pas non plus qu'un programme national slovène a été publié en 1987 dans une revue littéraire slovène (Nova Revija), reproduit en serbo-croate en 1988 dans une revue de sciences sociales zagréboise (Naše teme). Mais ces défauts sont mineurs, n'ayant qu'un rapport très éloigné avec le sujet traité.

\section{AUTEURS}

\section{PATRICK MICHELS}

